\title{
Effect of inhaled corticosteroids on bronchial responsiveness in patients with "corticosteroid naive" mild asthma: a meta-analysis
}

\author{
P M van Grunsven, C P van Schayck, J Molema, R P Akkermans, C van Weel
}

\begin{abstract}
Background-Inhaled corticosteroids are the most efficacious anti-inflammatory drugs in asthma. International guidelines also advocate the early introduction of inhaled corticosteroids in corticosteroid naive patients. A study was undertaken to assess the effects of inhaled corticosteroids on bronchial hyperresponsiveness in patients with corticosteroid naive asthma by conventional meta-analysis.

Methods-A Medline search of papers published between January 1966 and June 1998 was performed and 11 papers were selected in which the patients had no history of treatment with inhaled or oral corticosteroids. Bronchial responsiveness to bronchoconstricting agents was considered as the main outcome parameter. Doubling doses (DD) of histamine or methacholine were calculated.

Results-The total effect size of inhaled corticosteroids (average daily dose $1000 \mu \mathrm{g})$ versus placebo in the 11 studies was +1.16 DD $(95 \%$ confidence interval (CI) +0.76 to +1.57$)$. When only the eight short term studies (2-8 weeks) were analysed the effect size of the bronchoconstricting agent was +0.91 DD (95\% CI +0.65 to +1.16$)$. No relationship was found between the dose of inhaled corticosteroid used and the effect on bronchial responsiveness.

Conclusion-This meta-analysis in patients with corticosteroid naive asthma indicates that, on average, high doses of inhaled corticosteroids decrease bronchial hyperresponsiveness in 2-8 weeks. It remains unclear whether there is a doseresponse relationship between inhaled corticosteroids and effect on bronchial hyperresponsiveness.

(Thorax 1999;54:316-322)
\end{abstract}

Keywords: inhaled corticosteroids; corticosteroid naive asthma; bronchial hyperresponsiveness

Asthma is a chronic inflammatory disease of the airways. ${ }^{1}$ Inflammatory cells (mast cells, eosinophils, lymphocytes, and macrophages) are present even in patients with mild asthma. ${ }^{2}$ Levels of bronchoconstrictor mediators such as histamine and prostaglandins, which are known to be associated with inflammation, are also increased in mild asthma. ${ }^{3}$ Inhaled corticosteroids are the most effective antiinflammatory drugs. ${ }^{1}$ There are indications that early introduction of inhaled corticosteroids may prevent remodelling of the airway epithelium in patients with asthma and thus irreversible loss of lung function. ${ }^{1}$ Recently revised international consensus reports on asthma therefore advocate the administration of inhaled corticosteroids not only in moderate and severe asthma, but also in mild asthma. ${ }^{14}$ One of the new recommendations for rapid control of mild asthma is to start treatment with higher daily doses of inhaled corticosteroids (up to $1000 \mu \mathrm{g}$ ) than in earlier reports $(200-400 \mu \mathrm{g}) .^{56}$ Surprisingly, no systematic reviews on the effects of inhaled corticosteroids in patients with mild corticosteroid naive asthma are available to support this recommendation. Hatoum et al performed a meta-analysis of the effects of treatment with inhaled corticosteroids in patients with mild chronic asthma based on five published articles $^{7}$ and found a significant increase in the peak expiratory flow (PEF) after treatment. However, PEF was the only main outcome parameter used. No measure indicative of bronchial inflammation was included. Furthermore, the previous use of inhaled corticosteroids was not an exclusion criterion of the meta-analysis. It is therefore possible that in all cases the asthma was "mild" because of a previous successful treatment with inhaled corticosteroids.

We have therefore performed a meta-analysis of all randomised controlled studies of inhaled corticosteroids in patients with corticosteroid naive mild asthma. Patients with mild asthma have nearly normal spirometric values and few symptoms, while significant bronchial inflammation is present. Bronchial hyperresponsiveness (BHR), which is considered by many as an indirect measure of inflammation, was therefore used as the main clinical outcome parameter of the meta-analysis. We also assessed the minimum dose of inhaled corticosteroid and the minimum duration of treatment required to obtain a significant improvement in BHR.

\section{Methods}

INCLUSION AND EXCLUSION CRITERIA

Studies were only included if they reported trials on the clinical effects of inhaled corticosteroids in patients with corticosteroid naive mild asthma as indicated in the title or abstract, if they followed a randomised controlled design, and if they had a duration of at least two weeks. Exclusion criteria included a history of treatment with inhaled corticosteroids, absence of the assessment of BHR or the absence of 


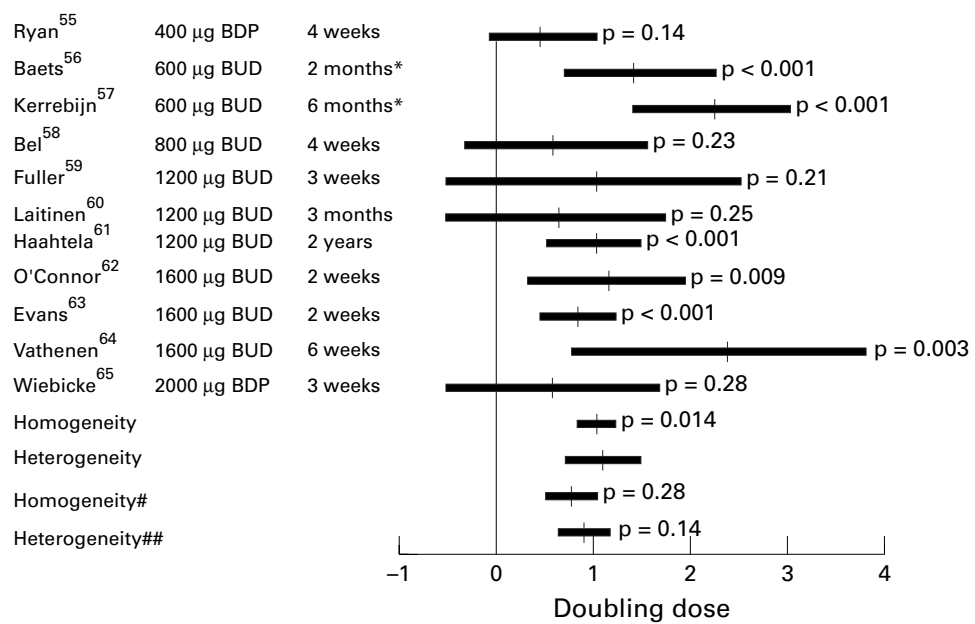

Figure 1 Effect size of inhaled corticosteroids on bronchial responsiveness in doubling doses of bronchoconstricting agent with $95 \%$ confidence intervals and $p$ values. The effect size within each selected study and the overall estimate are presented. Daily doses of inhaled corticosteroids are given. $B U D=$ budesonide; $B D P=$ beclomethasone; $\star_{\text {studies in children; }}$ \#only studies in adults; \#\# only studies of $\leqslant 2$ months.

adequate data about the BHR (either original data or effect size with standard errors in both the inhaled corticosteroid and placebo groups).

\section{SELECTION PROCEDURE}

A Medline search was performed for papers published between January 1966 and June 1998 with the following "free text" words: "beclomethasone", "budesonide", "fluticasone", "triamcinolone", "flunisolide", "inhaled (cortico)steroid(s)", "asthma(tic)(s)", "mild", "moderate", "(cortico)steroid naive", "newly detected", "newly diagnosed", "non(cortico) steroid dependent". The search yielded 258 English references. All abstracts of the retrieved references were checked manually. Thirty nine papers concerned the pathophysiology of inhaled corticosteroids, 24 were general reviews or consensus reports on inhaled corticosteroids, and 20 discussed the adverse effects of inhaled corticosteroids. One hundred and three papers presented the effects of inhaled corticosteroids in various conditions such as rhinitis and pregnancy, and tolerance to $\beta$ agonists. Seventy two papers included controlled as well as uncontrolled clinical trials of the clinical effects of inhaled corticosteroids in mild asthma. The reference lists of these studies were also checked for additional references.

By this method, 58 randomised controlled clinical trials assessing the effects of inhaled corticosteroids in patients with "mild to moderate asthma" were selected, ${ }^{8-65}$ all but one of which ${ }^{8}$ had a duration of two or more weeks. The method section of 39 of the remaining 57 papers stated that some of the patients included had a history of treatment with inhaled or oral corticosteroids. ${ }^{9-47}$ These studies were excluded from the systematic analysis. In three studies ${ }^{48-50}$ BHR had not been measured and these were excluded. Four of the 15 selected studies ${ }^{51-54}$ contained data on the bronchoconstricting agent which were incomplete for estimating the true effect size (and SE) of inhaled corticosteroids versus placebo and therefore were not included in the analysis.
Eleven studies were therefore left for inclusion in the meta-analysis. None of these studies assessed dose-response relationships.

QUALITY ASSESSMENT OF THE CONTROLLED STUDIES SELECTED

All 11 clinical trials selected for the review were checked by means of a criteria list for quality assessment of randomised clinical trials based on a recent Delphi consensus. ${ }^{66}$ When the method section contained information about a specific item on the Delphi list a score of one point was given. In the absence of information or if there was a negative answer to a specific question zero points were given. The total score ranged from 0 to 9 , a higher score representing a higher quality. Arbitrarily, studies with a score below 6 were judged to be of insufficient quality and were not reviewed. ${ }^{66}$

EVALUATION OF BRONCHIAL HYPERRESPONSIVENESS (BHR)

Bronchial hyperresponsiveness to bronchoconstricting agents was considered as the main outcome measure. The assessment of BHR differed widely between the studies, depending on the method (methods according to Hargreave, ${ }^{52}{ }^{55}$ Eiser, ${ }^{56}{ }^{57}$ Chai ${ }^{65}$ Sterk, ${ }^{58}$ Yan ${ }^{64}$ or test method not mentioned ${ }^{5159-62}$ ), the bronchoconstricting agent (histamine, methacholine, propranolol), and the expression method used $\left(\mathrm{PD}_{20}, \mathrm{PC}_{15}\right.$, or $\mathrm{PD}_{35}$ in $\mathrm{mg} / \mathrm{ml}, \mu \mathrm{g}$ or $\mu \mathrm{mol})$. Each of the agents was administered from the lowest concentration up to the minimal concentration inducing a specific fall in forced expiratory volume in one second $\left(\mathrm{FEV}_{1}\right)$. To compare the effects of inhaled corticosteroids on BHR between the studies, doubling doses (DD) of the triggers $\left(\log _{2}\right.$ transformed) were calculated (if not already done in the study). An increase of 1 DD of the trigger after treatment with inhaled corticosteroids meant that double the amount of the trigger was needed to achieve the same fall in $\mathrm{FEV}_{1}$. In studies in which more than one irritant was used for the assessment of BHR only the most common irritant (histamine, methacholine) was evaluated. ${ }^{56596265}$

\section{PROCEDURE OF THE META-ANALYSIS}

In each study within the trial groups the difference in dose steps was determined by final minus baseline assessment. When values were expressed as $\log _{10}$ we used the formula $\log _{10}$ (final assessment) minus $\log _{10}$ (baseline assessment) divided by $\log _{10} 2$. To determine the SD of the differences, variances in the independent observations were used. When the variables $x$ and $y$ were considered, the variance was: $\operatorname{var}(x-y)=\operatorname{var}(x)+\operatorname{var}(y)-2 \times$ covariance $(x y)$ or, in another formula: $\operatorname{var}(x-$ $y)=\operatorname{var}(x)+\operatorname{var}(y)-2 \times$ correlation coefficient $\times \mathrm{SD}(x) \times \mathrm{SD}(y)$. This correlation coefficient could only be assessed within the studies in which all individual data were presented. The mean of these coefficients was used as an "estimated" correlation coefficient within the remaining studies. The SD was assessed as the root of $\operatorname{var}(x-y)$. 
Table 1 Randomised controlled clinical trials on the effects of inhaled corticosteroids in patients with corticosteroid naive asthma

\begin{tabular}{|c|c|c|c|c|c|}
\hline Study & $\begin{array}{l}\text { No. of patients, age, } \\
\text { diagnosis }\end{array}$ & $\begin{array}{l}\text { Duration of } \\
\text { asthma }\end{array}$ & Main eligibility criteria & $\begin{array}{l}\text { Design and } \\
\text { duration }\end{array}$ & Intervention, daily dose \\
\hline $\operatorname{Ryan}^{55}$ & $\begin{array}{l}10,22-38 \mathrm{y}, \\
\text { controlled, } \\
\text { non-steroid } \\
\text { dependent asthma }\end{array}$ & Not specified & $\begin{array}{l}\text { Variability in } \mathrm{FEV}_{1}>20 \%, \mathrm{BHR} \text {, } \\
\text { only bronchodilators }\end{array}$ & $\begin{array}{l}\mathrm{DB}, \mathrm{CO}, \\
4 \text { weeks }\end{array}$ & $\begin{array}{l}400 \mu \mathrm{g} \text { BDP vs. } \\
\text { placebo, MDI }\end{array}$ \\
\hline Baets $^{56}$ & $\begin{array}{l}31,7-14 \mathrm{y}, \text { mild } \\
\text { atopic asthma }\end{array}$ & Not specified & $\begin{array}{l}\mathrm{FEV}_{1} \geqslant 75 \% \text { pred, cromoglycate } \\
\text { and/or bronchodilators, no } \\
\text { dependence on (oral) } \\
\text { corticosteroids }\end{array}$ & $\begin{array}{l}\mathrm{DB}, \mathrm{P}, \\
2 \text { months }\end{array}$ & $\begin{array}{l}600 \mu \mathrm{g} \text { BUD vs. } \\
\text { placebo, } \mathrm{MDI}+\text { spacer }\end{array}$ \\
\hline Kerrebijn $^{57}$ & $\begin{array}{l}19,7-16 \mathrm{y} \text {, allergic } \\
\text { asthma }\end{array}$ & Not specified & $\begin{array}{l}\mathrm{PD}_{20} \text { methacholine }<150 \mu \mathrm{g}, \\
\mathrm{FEV}_{1} \geqslant 80 \% \text { pred, no continuous } \\
\text { medication }\end{array}$ & $\begin{array}{l}\text { DB, } \mathrm{P}, \\
6 \text { months }\end{array}$ & $\begin{array}{l}600 \mu \mathrm{g} \text { BUD vs. } 1500 \\
\mu \mathrm{g} \text { terbutaline, } \mathrm{MDI}\end{array}$ \\
\hline $\mathrm{Bel}^{58}$ & $\begin{array}{l}16,19-38 \mathrm{y}, \text { mild } \\
\text { atopic asthma }\end{array}$ & Not specified & $\begin{array}{l}\text { Non-smoking, } \mathrm{FEV}_{1}>80 \% \text { pred, } \\
\mathrm{PC}_{20} \text { methacholine } 1-7 \mathrm{mg} / \mathrm{ml} \text {. } \\
\text { No inhaled or oral } \\
\text { corticosteroids in the past }\end{array}$ & $\begin{array}{l}\mathrm{DB}, \mathrm{P}, \\
4 \text { weeks }\end{array}$ & $\begin{array}{l}800 \mu \mathrm{g} \text { BUD vs. } \\
\text { placebo, Turbohaler }\end{array}$ \\
\hline Fuller $^{59}$ & $\begin{array}{l}10,18-45 \mathrm{y} \text {, atopic } \\
\text { mild asthma }\end{array}$ & Not specified & $\begin{array}{l}\text { Requiring only irregular therapy } \\
\text { with inhaled } \beta_{2} \text { agonists }\end{array}$ & $\begin{array}{l}\mathrm{DB}, \mathrm{CO} \\
3 \text { weeks }\end{array}$ & $\begin{array}{l}1200 \mu \mathrm{g} \text { BUD vs. } \\
\text { placebo, MDI + spacer }\end{array}$ \\
\hline Laitinen $^{60}$ & $\begin{array}{l}14,21-59 \text { y, newly } \\
\text { diagnosed asthma }\end{array}$ & $\begin{array}{l}7.4 \text { months } \\
\text { (range } 2-12 \text { ) }\end{array}$ & No previous regular treatment & $\begin{array}{l}\mathrm{DB}, \mathrm{P}, \\
3 \text { months }\end{array}$ & $\begin{array}{l}1200 \mu \mathrm{g} \text { BUD vs. } 750 \\
\mu \mathrm{g} \text { terbutaline, } \mathrm{MDI}+ \\
\text { spacer }\end{array}$ \\
\hline Haahtela $^{61}$ & $\begin{array}{l}103,15-64 \mathrm{y} \text {, newly } \\
\text { detected asthma }\end{array}$ & $\begin{array}{l}\text { Symptoms } \\
<12 \text { months }\end{array}$ & $\begin{array}{l}\text { Symptoms }<1 \text { year, never used } \\
\text { regular medication, } \mathrm{FEV}_{1} \\
\text { reversibility }>15 \%, \mathrm{PC}_{15} \\
\text { histamine }<32 \mathrm{mg} / \mathrm{ml} \text {, no history } \\
\text { of regular treatment or } \\
\text { treatment with corticosteroids or } \\
\text { cromoglycate }\end{array}$ & $\begin{array}{l}D B, P, \\
2 \text { years }\end{array}$ & $\begin{array}{l}1200 \mu \mathrm{g} \text { BUD vs. } 750 \\
\mu \mathrm{g} \text { terbutaline, } \mathrm{MDI}+ \\
\text { spacer }\end{array}$ \\
\hline $\mathrm{O}^{\prime}$ Connor $^{62}$ & $\begin{array}{l}12,20-27 \mathrm{y} \text {, mild } \\
\text { asthma }\end{array}$ & Not specified & $\begin{array}{l}\text { BHR, atopy, only occasional } \\
\text { symptoms controlled by } \beta_{2} \\
\text { agonist, } \mathrm{FEV}_{1}>80 \% \text { pred }\end{array}$ & $\begin{array}{l}\mathrm{DB}, \mathrm{CO}, \\
2 \text { weeks }\end{array}$ & $\begin{array}{l}1600 \mu \mathrm{g} \text { BUD vs. } \\
\text { placebo, Turbohaler }\end{array}$ \\
\hline Evans $^{63}$ & $\begin{array}{l}10,20-46 \mathrm{y} \text {, mild } \\
\text { stable ashma }\end{array}$ & Not specified & $\begin{array}{l}\mathrm{FEV}_{1}>80 \% \text { pred, atopic } \\
\text { non-smoking, occasional } \\
\text { symptoms controlled only by } \beta_{2} \\
\text { agonist }\end{array}$ & $\begin{array}{l}\mathrm{DB}, \mathrm{CO}, \\
2 \text { weeks }\end{array}$ & $\begin{array}{l}1600 \mu \mathrm{g} \text { BUD vs. } \\
\text { placebo, Turbohaler }\end{array}$ \\
\hline Vathenen $^{64}$ & $\begin{array}{l}40,18-45 \mathrm{y} \text {, mild to } \\
\text { moderate asthma }\end{array}$ & $\geqslant 2$ years & $\begin{array}{l}\mathrm{FEV}_{1}>50 \% \text { pred, } \mathrm{PD}_{20} \\
\text { histamine } \leqslant 4 \mu \mathrm{mol} \text {, current } \\
\text { non-smokers, no treatment } \\
\text { other than an inhaled } \beta_{2} \text { agonist }\end{array}$ & $\begin{array}{l}\mathrm{DB}, \mathrm{P} \\
6 \text { weeks }\end{array}$ & $\begin{array}{l}1600 \mu \mathrm{g} \text { BUD vs. } \\
\text { placebo, MDI + spacer }\end{array}$ \\
\hline Wiebicke $^{65}$ & $\begin{array}{l}25 \text {, adults, } \\
\text { asymptomatic or mild } \\
\text { asthma }\end{array}$ & Not specified & $\begin{array}{l}\mathrm{FEV}_{1}>75 \% \text { pred, no regular } \\
\text { medication required, } \\
\text { non-smokers, BHR present }\end{array}$ & $\begin{array}{l}\mathrm{DB}, \mathrm{P}, \\
3 \text { weeks }\end{array}$ & $\begin{array}{l}2000 \mu \mathrm{g} \text { BDP }+800 \mu \mathrm{g} \\
\text { salbutamol vs. placebo } \\
+800 \mu \mathrm{g} \text { salbutamol, } \\
\mathrm{MDI}+\text { spacer }\end{array}$ \\
\hline
\end{tabular}

$\mathrm{DB}=$ double blind $\mathrm{P}=$ parallel; $\mathrm{CO}=$ crossover; $\mathrm{BDP}=$ beclomethasone dipropionate; $\mathrm{BUD}=$ budesonide MDI = metered dose inhaler; $\mathrm{BHR}=$ bronchial hyperresponsiveness; $\mathrm{FEV}_{1}=$ forced expiratory volume in one second; $\mathrm{PC}_{20}$ or $\mathrm{PD}_{20}=$ concentration or dose of provocative agent required to reduce $\mathrm{FEV}_{1}$ by $20 \%$ or more; $\mathrm{DD}=$ doubling dose.

Assessment of the overall effect size was based on the method of DerSimonian and Laird. ${ }^{67}$ The effect size of inhaled corticosteroids versus control was assessed by subtracting the independent effects (effect of inhaled corticosteroid compared with placebo, unpaired $t$ test). In fig 1 the effect size within each study is presented in DD with $95 \%$ confidence intervals (CI) and $p$ values. The estimate was assessed under the condition of homogeneity. In case of significance $\left(\chi^{2}\right.$ test, $\left.p<0.05\right)$ the estimate was assessed under the condition of heterogeneity. Reasons for heterogeneity were investigated, if appropriate.

The doses of inhaled corticosteroids used were related to the effect sizes in two different ways. Firstly, a univariate regression analysis was used to relate increasing doses of inhaled corticosteroid to the effect size of BHR and, secondly, a Wilcoxon rank test was used to compare the effect size of high doses $(\geqslant 1000 \mu \mathrm{g}$ daily) and low doses $(<1000 \mu \mathrm{g}$ daily) of inhaled corticosteroids. It is doubtful whether a dose of $600 \mu \mathrm{g}$ daily is "low" for children, so we also assessed the dose-response relationship omitting the two studies in children.

To determine whether inhaled corticosteroids would be able to decrease bronchial responsiveness in short term studies we re- peated the above analysis using only studies with a maximum duration of $2-8$ weeks.

\section{Results}

QUALITY OF STUDIES

All 11 studies selected were of sufficient quality to be reviewed. Four studies were rated as being of high quality (score of 8$)^{57586164}$ and the remaining seven were of sufficient quality. Most of the 11 studies failed to give an explicit description of the method of concealed treatment allocation or intention to treat analysis.

METHOD OF STUDIES

Table 1 shows the study populations, eligibility criteria, design and intervention of the 11 studies. Two studies were performed in children with atopic asthma. ${ }^{5657}$ One study recruited 103 patients and was a long term study. ${ }^{61}$ Patient numbers in the other studies varied from 10 to 40 subjects. Eligibility criteria differed widely between the studies, although all studies excluded subjects who had previously received regular treatment with inhaled corticosteroid. The duration of most of the studies varied from two weeks to three months. One study lasted six months, ${ }^{57}$ and another for two years. ${ }^{61}$ Nine studies compared the effects of inhaled corticosteroids with placebo and six with $\beta_{2}$ agonists. The average 
Table 2 Randomised controlled clinical trials on the effects of inhaled corticosteroids in patients with corticosteroid naive asthma

\begin{tabular}{|c|c|c|c|c|c|c|}
\hline Study & Major outcome measures & $\begin{array}{l}\text { Mean baseline BHR } \\
\text { (range of doses } \\
\text { applied) }\end{array}$ & $\begin{array}{l}\text { Mean baseline } \\
F E V_{1}\end{array}$ & $\begin{array}{l}\text { Effects on BHR } \\
\text { (inhaled } \\
\text { corticosteroid vs. } \\
\text { control) }\end{array}$ & $\begin{array}{l}\text { Effects on lung function } \\
\text { (inhaled corticosteroid vs. } \\
\text { control) }\end{array}$ & $\begin{array}{l}\text { Effects on symptoms, } \beta_{2} \text { agonists } \\
\text { and bronchial } \\
\text { epithelium/eosinophils (inhaled } \\
\text { corticosteroids vs. control) }\end{array}$ \\
\hline Ryan $^{55}$ & $\mathrm{PC}_{20}$ histamine & $\begin{array}{l}0.5 \mathrm{mg} / \mathrm{ml} \text { histamine } \\
(0.0125-16)\end{array}$ & 3.181 & $\begin{array}{l}+0.44 \mathrm{DD} \\
(\mathrm{p}=0.14)\end{array}$ & $\mathrm{FEV}_{1}=$ & No data \\
\hline Baets $^{56}$ & $\mathrm{PD}_{20}$ histamine/HDM & $\begin{array}{l}50 \mu \mathrm{g} \text { histamine } \\
(10-1280)\end{array}$ & $90 \%$ pred & $\begin{array}{l}+1.55 \mathrm{DD} \\
(\mathrm{p}<0.001)\end{array}$ & $\begin{array}{l}\mathrm{FEV}_{1}+(97 \%), \text { morning } \\
\mathrm{PEF}+(201 / \mathrm{min})\end{array}$ & Symptoms $=, \beta_{2}$ agonists - \\
\hline Kerrebijn $^{57}$ & $\mathrm{PD}_{20}$ methacholine & $\begin{array}{l}38 \mu \mathrm{g} \text { methacholine } \\
(10-1280)\end{array}$ & $95 \%$ pred & $\begin{array}{l}+2.33 \mathrm{DD} \\
(\mathrm{p}<0.001)\end{array}$ & $\mathrm{FEV}_{1}=$ & Symptoms $=$ \\
\hline $\mathrm{Bel}^{58}$ & $\begin{array}{l}\mathrm{PC}_{20} \text { methacholine, } \max \\
\text { airway narrowing } \\
\text { methacholine }\end{array}$ & $\begin{array}{l}3.6 \mathrm{mg} / \mathrm{ml} \\
\text { methacholine } \\
(0.25-256)\end{array}$ & $94 \%$ pred & $\begin{array}{l}+0.65 \mathrm{DD} \\
(\mathrm{p}=0.23)\end{array}$ & $\mathrm{FEV}_{1}=$ & No data \\
\hline Fuller $^{59}$ & $\mathrm{PD}_{35}$ histamine/bradykinin & $\begin{array}{l}0.28 \mu \mathrm{mol} \text { histamine } \\
(0.06-16)\end{array}$ & $89 \%$ pred & $\begin{array}{l}+1.00 \mathrm{DD} \\
(\mathrm{p}=0.21)\end{array}$ & $\begin{array}{l}\mathrm{FEV}_{1}=, \mathrm{PEF}+ \\
(35-501 / \mathrm{min})\end{array}$ & Symptoms $=$ \\
\hline Laitinen $^{60}$ & $\begin{array}{l}\mathrm{PC}_{15} \text { histamine, } \mathrm{FEV}_{1}, \mathrm{PEF}, \\
\text { symptoms, biopsy: } \\
\text { bronchial epithelium, } \\
\text { inflammatory cells mucosa }\end{array}$ & $\begin{array}{l}2.9 \mathrm{mg} / \mathrm{ml} \text { histamine } \\
(1.0-32)\end{array}$ & $89 \%$ pred & $\begin{array}{l}+0.70 \mathrm{DD} \\
(\mathrm{p}=0.25)\end{array}$ & $\begin{array}{l}\mathrm{FEV}_{1}=, \mathrm{PEF}+ \\
(501 / \mathrm{min})\end{array}$ & $\begin{array}{l}\text { Symptoms }=, \beta_{2} \text { agonists }=, \\
\text { structure airway epithelium }+ \text {, } \\
\text { lymphocytes }- \text {, eosinophils - }\end{array}$ \\
\hline Haahtela $^{61}$ & $\begin{array}{l}\mathrm{PC}_{15} \text { histamine, } \mathrm{FEV}_{1}, \mathrm{PEF}, \\
\text { symptoms, } \beta \text { agonists }\end{array}$ & $\begin{array}{l}7.0 \mathrm{mg} / \mathrm{ml} \text { histamine } \\
(1.0-32)\end{array}$ & $86 \%$ pred & $\begin{array}{l}+1.10 \mathrm{DD} \\
(\mathrm{p}<0.001)\end{array}$ & $\begin{array}{l}\mathrm{FEV}_{1}=, \mathrm{PEF}+ \\
(301 / \mathrm{min})\end{array}$ & Symptoms,$- \beta_{2}$ agonists - \\
\hline $\mathrm{O}^{\prime}$ Connor $^{62}$ & $\begin{array}{l}\mathrm{PC}_{20} \text { methacholine/MBS/ } \\
\mathrm{AMP}\end{array}$ & $\begin{array}{l}1.4 \mathrm{mg} / \mathrm{ml} \\
\text { methacholine } \\
(0.125-32)\end{array}$ & $96 \%$ pred & $\begin{array}{l}+1.17 \mathrm{DD} \\
(\mathrm{p}=0.009)\end{array}$ & $\mathrm{FEV}_{1}=$ & No data \\
\hline Evans $^{63}$ & $\begin{array}{l}\text { Peripheral blood } \\
\text { eosinophils, } \mathrm{PC}_{20} \\
\text { methacholine }\end{array}$ & $\begin{array}{l}0.13-2.23 \mathrm{mg} / \mathrm{ml} \\
\text { methacholine } \\
(0.125-32)\end{array}$ & $96 \%$ pred & $\begin{array}{l}+0.88 \mathrm{DD} \\
(\mathrm{p}<0.001)\end{array}$ & No data & $\begin{array}{l}\text { No data about symptoms } / \beta_{2} \\
\text { agonists, eosinophils - }\end{array}$ \\
\hline Vathenen ${ }^{64}$ & $\begin{array}{l}\mathrm{PD}_{20} \text { histamine, } \mathrm{FEV}_{1}, \mathrm{PEF}, \\
\text { symptoms, } \beta \text { agonists }\end{array}$ & $\begin{array}{l}0.37 \mu \mathrm{mol} \text { histamine } \\
(0.03-32)\end{array}$ & $95 \%$ pred & $\begin{array}{l}+2.40 \mathrm{DD} \\
(\mathrm{p}=0.003)\end{array}$ & $\begin{array}{l}\mathrm{FEV}_{1}+(98 \%), \mathrm{PEF}+ \\
(401 / \mathrm{min})\end{array}$ & Symptoms,$- \beta_{2}$ agonists - \\
\hline Wiebicke $^{65}$ & $\begin{array}{l}\mathrm{PC}_{100} \text { sRaw } \\
\text { histamine/methacholine, } \\
\mathrm{PV}_{75} \text { sRaw hypervent } / \mathrm{SO}_{2}\end{array}$ & $\begin{array}{l}0.2 \mathrm{mg} / \mathrm{ml} \text { histamine } \\
(0.01-8.0)\end{array}$ & $90 \%$ pred & $\begin{array}{l}+0.64 \mathrm{DD} \\
\text { (histamine or } \\
\text { methacholine) } \\
(\mathrm{p}=0.28)\end{array}$ & No data & No data \\
\hline
\end{tabular}

$\mathrm{BHR}=$ bronchial hyperresponsiveness $; \mathrm{DD}=$ doubling dose $\mathrm{FEV}_{1}=$ forced expiratory volume in one second $;$ PEF $=$ peak expiratory flow $;$ Raw $=$ specific airways resistance; $\mathrm{SO}_{2}=$ oxygen saturation; $\mathrm{PC}_{20}, \mathrm{PD}_{20}=$ concentration or dose of provocative agent required to produce a fall in $\mathrm{FEV}$, of $20 \%$ or more.; $\mathrm{HDM}=$ house dust mite. According to effects of inhaled corticosteroids versus control group on lung function and symptoms, '+' or ' - ' means statistically significant increase or decrease $(\mathrm{p}<0.05)$, ' $=$ ' means no statistically significant difference. ${ }^{\star}$ See fig 1 .

daily dosage of inhaled corticosteroids (budesonide or beclomethasone) used was $1000 \mu \mathrm{g}$ (range $400-2000 \mu \mathrm{g}$ ).

EFFECTS ON BHR

Baseline BHR levels were in the mild asthmatic range in five of the studies ${ }^{58-63}$ and in the moderate asthmatic range in the remaining studies (table 2).

The overall effect on BHR of inhaled corticosteroids compared with control was measured by accumulating the separate effect sizes of the 11 selected studies. For that purpose the original individual data ${ }^{55} 59$ or mean $\log _{10}$ values, doubling doses, or geometric mean with SE or $95 \%$ CI of histamine or methacholine were subtracted ${ }^{56-5862-64}$ or assessed on the basis of the graphics ${ }^{60}$ for all studies separately.

Effect sizes were all in favour of the inhaled corticosteroids, ranging from +0.44 to +2.40 DD of the bronchoconstricting agent (table 2). However, fig 1 shows that in five of the 11 studies the inhaled corticosteroid did not have a significant effect on BHR compared with placebo. ${ }^{55}$ 58-60 65

The total effect size of inhaled corticosteroids versus placebo of the 11 studies was $+1.16 \mathrm{DD}(95 \% \mathrm{CI}+0.76$ to +1.57 , test of heterogeneity) which was statistically significant. The confidence intervals of the effect size in the study by Baets et al in children did not fall within the confidence interval of the total effect size when assessed under conditions of homogeneity $(\mathrm{p}=0.014)$. To determine whether heterogeneity could be explained by the variation in age we also assessed the total effect size without the two studies in children ${ }^{56}{ }^{57}$ but the total effect size remained statistically significant $(+0.88 \mathrm{DD}$ of the bronchoconstricting agent $(95 \%$ CI +0.64 to $+1.14)$ ).

A univariate regression analysis was used to measure any dose-response relationship between the dose of inhaled corticosteroid and the level of BHR. This analysis showed no statistically significant relationship (regression coefficient $-0.007 \mathrm{DD} / 100 \mu \mathrm{g}, \mathrm{p}=0.87$ ). Correcting for study duration did not improve the relationship between the dose of inhaled corticosteroids and decrease in BHR, nor was there a statistically significant effect found when the patients were divided into two groups according to the dose of inhaled corticosteroid $(<1000 \mu \mathrm{g}$ daily, four studies, total effect +1.25 $\mathrm{DD} ; \geqslant 1000 \mu \mathrm{g}$, seven studies, total effect +1.13 DD; $p=0.92$, Wilcoxon rank test). This difference in effect was somewhat higher than in the previous analyses ( $p$ values "fell" to $p=$ 0.29 and $\mathrm{p}=0.11$, respectively) when the two studies in children $(600 \mu \mathrm{g}$ daily) were excluded.

We were also interested to determine whether inhaled corticosteroids were able to decrease BHR during short term treatment. A positive result was seen in four of the eight studies with a relatively short duration of $2-8$ weeks ${ }^{562-64}$ and a negative result was seen in the other four. ${ }^{555859}$ We combined the separate study effects in these short term studies to assess the overall effect size of inhaled corticosteroids compared with control on BHR. The effect size under the condition of homogeneity was +0.91 DD $(95 \%$ CI +0.65 to +1.16 ) of the bronchoconstrictor in favour of the inhaled corticosteroid $(\mathrm{p}=0.14)$. We also 
related the effect sizes of individual studies to the dose of inhaled corticosteroids used in the short term studies by univariate regression analysis which gave a regression coefficient of $+0.02 \mathrm{DD} / 100 \mu \mathrm{g}(\mathrm{p}=0.38)$. Correcting for study duration did not improve the relationship between the dose of inhaled corticosteroids and decrease in BHR. A comparison of low dose $(<1000 \mu \mathrm{g}, 3$ of 8 studies $)$ versus high dose inhaled corticosteroids also showed a lack of correlation between the dose used and the level of BHR (+0.88 DD versus +1.21 DD, respectively; $\mathrm{p}=0.55$, Wilcoxon rank test).

\section{Discussion}

Inhaled corticosteroids are increasingly considered as first line treatment for asthma, even in milder stages of the disease. ${ }^{14}$ The degree of $\mathrm{BHR}$ is considered to be indirectly related to the degree of bronchial inflammation. This meta-analysis in patients with corticosteroid naive asthma indicated that, on average, high doses of inhaled corticosteroids (mean dose $1000 \mu \mathrm{g}$, range 400-2000 $\mu$ g daily) decreased BHR significantly within $2-8$ weeks. This finding supports recent consensus reports recommending the use of relatively high initial doses of inhaled corticosteroids in mild bronchial inflammation. ${ }^{14}$ There were insufficient studies to determine whether doses below $1000 \mu \mathrm{g}$ daily would have been able to produce the same result.

Inhaled corticosteroids have been shown to be the most effective inhaled anti-inflammatory agents available for the treatment of asthma and there are indications that the early introduction of inhaled corticosteroids may prevent loss of lung function. ${ }^{6}{ }^{8}$ In patients with mild (corticosteroid naive) asthma the advantages of inhaled corticosteroids have to be weighed against the disadvantages. Local side effects such as oral candidiasis and systemic side effects such as adrenal suppression have been reported, especially with higher doses of inhaled corticosteroids. ${ }^{69}$ It is important to recognise that control of BHR is an outcome which patients with few bronchial symptoms may not consider important and this may hamper patient compliance.

A few comments on the method of the metaanalysis have to be made. The purpose of the study was to assess the first time treatment effect of inhaled corticosteroids on bronchial inflammation so we searched the literature for studies of "corticosteroid naive" asthma. This may have led to confusion about the severity and duration of asthma of the studies included. Firstly, corticosteroid naive asthma is not necessarily mild, and patients with moderate to severe asthma could have been corticosteroid naive. Baseline BHR and $\mathrm{FEV}_{1}$ in most of the studies suggested mild to moderate asthma. Unfortunately, the duration of asthma was not stated in many of the studies so asthma of recent onset as well as longer standing asthma (mild or moderate) might have been present.

The method of assessment of BHR varied widely between the studies. In order to compare different measurements of BHR the effects were presented in doubling doses of the trigger. Although the DD is often used as a clinical and epidemiological effect parameter, the comparison between the different studies may have resulted in some bias. However, both histamine and methacholine are the best validated substances for provocation testing. ${ }^{70}$

Type 2 errors could have occurred as a number of the studies analysed might not have had enough power. A conventional metaanalysis was therefore performed to obtain a tighter estimate of the effect size than that obtained by several smaller (and possibly underpowered) studies. However, we are aware that such an analysis may not totally overcome these shortcomings of individual studies.

We performed a meta-analysis despite the diversity of the studies included. The studies contained populations of different ages (children and adults), asthma of different duration (less than one year to unspecified) and of slightly different severity, the use of different inhaled corticosteroids, different dosages of inhaled corticosteroids, and different study durations (two weeks to two years). These differences might have influenced the reliability of the results to some extent. However, the direction of effect sizes was always the same, and the different dosages and duration of the studies made it possible to estimate dosage and time effects of drug activity.

In this study the measurement of BHR as a hallmark of inflammation in asthma was the primary outcome parameter of the effects of inhaled corticosteroids in patients with corticosteroid naive mild asthma. The clinical relevance of an overall effect size of approximately 1 DD of the trigger after treatment with inhaled corticosteroids of patients with corticosteroid naive asthma is not yet clear. This difference is thought to be clinically relevant in patients with moderate and severe asthma. ${ }^{71}$ In those with corticosteroid naive asthma the improvement in BHR may be of greater importance because, in most cases, there is less room for improvement than in moderate and severe asthma. There are indications that bronchial inflammation precedes bronchial obstruction and thus probably symptoms in asthma. ${ }^{72}$ Patients with corticosteroid naive (mostly mild) asthma may have nearly normal spirometric parameters and few symptoms on testing. Improvements with treatment are therefore difficult to obtain. Measurement of BHR was therefore chosen as an indicator of bronchial lability. Nevertheless, in half of the 11 studies analysed there was a significant improvement in lung function (PEF and/or $\mathrm{FEV}_{1}$ ) after treatment with inhaled corticosteroids. $^{569-6164}$ Three of the six studies in which symptoms or the use of bronchodilators were evaluated reported a statistically significant decrease in one of these parameters after treatment with inhaled corticosteroids. ${ }^{566164}$

Most studies showed a clinically significant decrease in BHR after treatment with high doses of inhaled corticosteroids compared with the control drug. However, only in the two year study by Haahtela et al in patients with corticosteroid naive mild asthma did long term 
treatment with a high dose of inhaled corticosteroids eventually cause BHR to return to "non-asthmatic" levels. ${ }^{61}$ Although the first six weeks of treatment with inhaled corticosteroids contributed most to the effect on BHR, the $\mathrm{PC}_{15}$ histamine increased gradually during the two year study. A gradual decrease in the level of BHR during 12-24 months of treatment with inhaled corticosteroids was also reported in two studies in patients with moderate asthma. ${ }^{734}$ The six month study by Kerrebijn et al and the three month study by Laitinen et al also found that the first $6-8$ weeks of treatment with inhaled corticosteroids contributed most to the decrease in BHR. ${ }^{57}{ }^{60}$ In the light of these results we suggest that the dose could probably be tapered after six weeks to a lower dose $(200-400 \mu \mathrm{g})$, both to avoid adverse effects and gradually to diminish the inflammation in the long term.

No relationship between the dose of inhaled corticosteroids and the level of BHR was found. It is possible that the only low dose study included in the analysis ${ }^{55}$ (400 $\mu$ g daily) was too short to show an optimum improvement within the study period of four weeks, so we cannot fully exclude the possibility of a dose-response effect. Unfortunately, no studies were analysed in which dose-response relationships were tested. Larger and more long term studies are urgently needed in patients with corticosteroid naive asthma to assess the effects of first time treatment with inhaled corticosteroids at different dosages and periods of treatment on both BHR and lung function and symptoms.

In conclusion, this meta-analysis has indicated that, on average, high doses of inhaled corticosteroids (mean dose $1000 \mu \mathrm{g}$, range 400-2000 $\mu \mathrm{g}$ daily) decreases BHR within 2-8 weeks in patients with corticosteroid naive asthma. It remains unclear whether lower doses of inhaled corticosteroids can achieve the same results. In the meantime it may be wise to follow the recent treatment protocols of consensus reports on asthma advocating a top-down strategy with inhaled corticosteroids once control of symptoms has been achieved.

We are grateful to the Dutch Government Organization for Scientific Research for financial support. We would also like to thank Ms A L M Rouwhorst for her assistance with the figure.

1 National Institutes of Health. Highlights of the expert panel report 2: guidelines for the diagnosis and management of asthma. NIH Publication No. 97-4051A. Bethesda, Maryland: National Institutes of Health, 1997.

2 Laitinen LA, Laitinen A, Haahtela T. Airway mucosal inflammation even in patients with newly diagnosed inflammation even in patients with newly
asthma. Am Rev Respir Dis 1993;147:697-704.

3 Liu MC, Bleecker ER, Lichtenstein LM, et al. Evidence for elevated levels of histamine, prostaglandin $\mathrm{D}_{2}$, and other bronchoconstricting prostaglandins in the airways of subjects with mild asthma. Am Rev Respir Dis 1990;142: 126-32.

4 British Thoracic Society, et al. British guidelines on asthma management: 1995 review and position statement. Thorax 1997;52(Suppl 1):S1-21.

5 National Institutes of Health. International consensus report on diagnosis and treatment of asthma. National Heart, Lung,
and Blood Institute, NIH Publication No. 92-3091. Eur Respir f 1992;5:601-41.

6 British Thoracic Society, et al. Guidelines on the management of asthma. Thorax 1993;48(Suppl 2):S1-24.

7 Hatoum HT, Schumock GT, Kendzierski DL. Metaanalysis of controlled trials of drug therapy in mild chronic asthma: the role of inhaled corticosteroids. Ann Pharmacother 1994;28:1285-9.
8 Gauvreau GM, Doctor J, Watson RM, et al. Effects of inhaled budesonide on allergen-induced airway responses and airway inflammation. Am $\mathcal{F}$ Respir Crit Care Med 1996; 154:1267-71

9 Kuzemko JA, Bedford S, Wilson L, et al. A comparison of betamethasone valerate aerosol and sodium cromoglycate in children with reversible airways obstruction. Postgrad Med F 1974;50(Suppl 4):53-8.

$10 \mathrm{Ng} \mathrm{SH}$, Dash CH, Savage SJ. Betamethasone valerate compared with sodium cromoglycate in asthmatic children. postgrad Med $\mathcal{F} 1977 ; 53: 315-20$.

11 Kraan J, Koeter GH, van derMark TW, et al. Changes in bronchial hyperreactivity induced by 4 weeks of treatment with antiasthmatic drugs in patients with allergic asthma: a comparison between budesonide and terbutaline. F Allergy Clin Immunol 1985;76:628-36.

12 Dahl R, Pedersen B, Hagglof B. Nocturnal asthma: effect of treatment with oral sustained-release terbutaline, inhaled budesonide, and the two in combination. 7 Allergy Clin Immunol 1989;83:811-5.

13 Molema J, van Herwaarden CL, Folgering HT. Effects of long-term treatment with inhaled cromoglycate and budesonide on bronchial hyperresponsiveness in patients with allergic asthma. Eur Respir f 1989;2:308-16.

14 Bel EH, Timmers MC, Hermans J, et al. The long-term effects of nedocromil sodium and beclomethasone dipropionate on bronchial responsiveness to methacholine in nonatopic asthmatic subjects. Am Rev Respir Dis 1990;141:218.

15 Juniper EF, Kline PA, Vanzieleghem MA, et al. Effect of long-term treatment with an inhaled corticosteroid (budesonide) on airway hyperresponsiveness and clinical asthma in nonsteroid-dependent asthmatics. Am Rev Respir Dis 1990;142:832-6.

16 Campbell LM, Watson DG, Venables TL, et al. On behalf of The Maestro Research Group. Once daily budesonide turbohaler compared with placebo as initial prophylactic therapy for asthma. I Clin Res 1991;2:111-22.

17 Waalkens HJ, Gerritsen J, Koeter GH, et al. Budesonide and terbutaline or terbutaline alone in children with mild asthma: effects on bronchial hyperresponsiveness and diurnal variation in peak flow. Thorax 1991;46:499-503.

18 Kraemer R, Modelska K, Aebischer CC, et al. Comparison of different inhalation schedules to control childhood asthma. Agents Actions Suppl 1993;40:211-21.

19 O'Shaughnessy KM, Wellings R, Gillies B, et al. Differential effects of fluticasone propionate on allergen-evoked bronchoconstriction and increased urinary leukotriene E4 excretion. Am Rev Respir Dis 1993;147:1472-6.

20 Chervinsky P, van As A, Bronsky EA, et al. Fluticasone propionate aerosol for the treatment of adults with mild to moderate asthma. F Allergy Clin Immunol 1994;94:676-83.

21 Jones AH, Langdon CG, Lee PS, et al. Pulmicort Turbohaler once daily as initial prophylactic therapy for asthma. Respir Med 1994;88:293-9.

22 Kivity S, Fireman E, Greif J, et al. Effect of budesonide on bronchial hyperresponsiveness and pulmonary function in patients with mild to moderate asthma. Ann Allergy 1994;72:333-6.

23 Wang JH, Trigg CJ, Devalia JL, Effect of inhaled beclomethasone dipropionate on expression of proinflammatory cytokines and activated eosinophils in the bronchial epithelium of patients with mild asthma. F Allergy Clin Immunol 1994;94:1025-34.

24 Aldrey OE, Anez H, Deibis L, et al. A double-blind, cross-over study using salbutamol, beclomethasone, and a combination of both in bronchial asthma. F Asthma 1995;32:21-8.

25 Wongtim S, Mogmued S, Chareonlap P, et al. Effect of inhaled corticosteroids on bronchial hyperresponsiveness in patients with mild asthma. Asian Pac f Allergy Immunol 1995;13:81-5.

26 Wasserman SI, Gross GN, Schoenwetter WF, et al. A 12 -week dose-ranging study of fluticasone propionate powder in the treatment of asthma. F Asthma 1996;33:26574 .

27 Sheffer AL, LaForce C, Chervinsky P, et al. Fluticasone propionate aerosol: efficacy in patients with mild to moderate asthma. Fluticasone Propionate Asthma Study Group. $\mathcal{F}$ Fam Pract 1996;42:369-75.

28 Horn CR, Clark TJH, Cochrane GM. Can the morbidity of asthma be reduced by high dose inhaled therapy? Respir Med 1990;84:61-6.

29 Boe J, Rosenhall L, Alton M, et al. Comparison of dose-response effects of inhaled beclomethasone dipropionate and budesonide in the management of asthma. Allergy 1989;44:349-55.

30 Meltzer EO, Kemp JP, Welch MJ, et al. Effect of dosing schedule on efficacy of beclomethasone dipropionate aerosol in chronic asthma. Am Rev Respir Dis 1985;131:732-6.

31 MacKenzie CA, Weinberg EG, Tabachnik E, A placebo controlled trial of fluticasone propionate in asthmatic children. Eur F Pediatr 1993;152:856-60.

32 Juniper EF, Kline PA, Vanzieleghem MA. Long-term effects of budesonide on airway responsiveness and clinical asthma severity in inhaled steroid-dependent asthmatics. Eur Respir 7 1990;3:1122-7.

33 Haahtela T, Alanko K, Muittari A, et al. The superiority of combination beclomethasone and salbutamol over standard dosing of salbutamol in the treatment of chronic asthma. Ann Allergy 1989;62:63-6. 
34 Dahl R, Lundback B, Malo JL, et al. A dose-ranging study of fluticasone propionate in adult patients with moderate 8 .

35 Brompton Hospital/Medical Research Council Collaborative Trial. Double-blind trial comparing two dosage schedules of beclomethasone dipropionate aerosol with a placebo in chronic bronchial asthma. Second report. $\mathrm{Br} \mathcal{F}$ Dis Chest 1979;73:121-32.

36 Katz RM, Rachelefsky GS, Siegel SC, et al. Twice-daily beclomethasone dipropionate in the treatment of childhood asthma. F Asthma 1986;23:1-7.

37 Johansson SA, Dahl R. A double-blind dose-response study of budesonide by inhalation in patients with bronchial asthma. Allergy 1988;43:173-8.

38 Paggiaro PL, Dente FL, Vagaggini B, et al. Salbutamol plus beclomethasone dipropionate, but not salbutamol alone, completely prevent early and late asthmatic responses to allergen. Respir Med 1991;85:401-6.

39 Fuglsang G, Agertoft L, Vikre Jorgensen J, et al. Influence of budesonide on the response to inhaled terbutaline in budesonide on the response to inhaled terbutaline in
children with mild asthma. Pediatr Allergy Immunol 1995;6: children

40 Wolfe JD, Selner JC, Mendelson LM, et al. Effectiveness of fluticasone propionate in patients with moderate asthma: a dose-ranging study. Clin Ther 1996;18:635-46.

41 Hoekstra MO, Grol MH, Bouman K, et al. Fluticasone propionate in children with moderate asthma. Am f Respir Cri Care Med 1996;154:1039-44.

42 Pearlman DS, Noonan MJ, Tashkin DP, et al. Comparative efficacy and safety of twice daily fluticasone propionate powder versus placebo in the treatment of moderate asthma. Ann Allergy Asthma Immunol 1997;78:356-62.

43 Osterman K, Carlholm M, Ekelund J, et al. Effect of 1 year daily treatment with $400 \mu \mathrm{g}$ budesonide (Pulmicort Turbuhaler) in newly diagnosed asthmatics. Eur Respir F 1997;10: 2210-5.

44 Sekerel BE, Tuncer A, Saraclar Y, et al. Inhaled budesonide reduces lung hyperinflation in children with asthma. Acto reduces lung hyperinflation
Paediatr 1997;86:932-6.

45 Booms P, Cheung D, Timmers MC, et al. Protective effect of inhaled budesonide against unlimited airway narrowing to methacholine in atopic patients with asthma. $f$ Allergy Clin Immunol 1997:99:330

46 Olivieri D, Chetta A, Del Donno M, et al. Effect of short-term treatment with low-dose inhaled fluticasone propionate on airway inflammation and remodeling in mild asthma: a placebo-controlled study. Am f Respir Crit Care Med 1997;155:1864-71.

47 Noonan MJ, Chervinsky P, Wolfe J, et al. Dose-related response to inhaled fluticasone propionate in patients with methacholine-induced bronchial hyperresponsiveness: double-blind, placebo-controlled study. 7 Asthma 1998;35: 153-64.

48 Lorentzson S, Boe J, Eriksson G, et al. Use of inhaled corticosteroids in patients with mild asthma. Thorax 1990; 45:733-5.

49 Lovera J, Cooper DM, Collins Williams C, et al. Clinical and physiological assessment of asthmatic children treated with 1976;57:112-23.

50 Klein R, Waldman D, Kershnar H, et al. Treatment of chronic childhood asthma with beclomethasone dipropionate aerosol: I. A double-blind crossover trial in nonsteroiddependent patients. Pediatrics 1977;60:7-13.

51 Carpentiere G, Castello F, Marino S. Effect of beclomethasone dipropionate on the bronchial responsiveness to propranolol in asthmatics. Chest 1990;98:263-5.

52 Jeffery PK, Godfrey RW, Adelroth E. Effects of treatment on airway inflammation and thickening of basement membrane reticular collagen in asthma. A quantitative light and electron microscopic study. Am Rev Respir Dis 1992;145: $890-9$.

53 Hartley JPR. Effect of budesonide on bronchial hyperreactivity. Thorax 1984;39:706.

54 Haahtela T, Jarvinen M, Kava T, et al. First line treatment fot newly detected asthma; an inhaled steroid? $\mathcal{F}$ Allergy Clin Immunol 1990;85:199.
55 Ryan G, Latimer KM, Juniper EF, et al. Effect of Ryan $\mathrm{G}$, Latimer $\mathrm{KM}$, Juniper $\mathrm{EF}$, et al. Effect of
beclomethasone dipropionate on bronchial responsiveness beclomethasone dipropionate on bronchial responsiveness
to histamine in controlled nonsteroid-dependent asthma. $\mathcal{7}$ Allergy Clin Immunol 1985;75:25-30.

56 De Bats FM, Goeteyn M, Kerrebijn KF. The effect of two months of treatment with inhaled budesonide on bronchial responsiveness to histamine and house-dust mite antigen in asthmatic children. Am Rev Respir Dis 1990;142:581-6.

57 Kerrebijn KF, van Essen Zandvliet EE, Neijens HJ. Effect of long-term treatment with inhaled corticosteroids and betaagonists on the bronchial responsiveness in children with asthma. F Allergy Clin Immunol 1987;79:653-9.

58 Bel EH, Timmers MC, Zwinderman AH. The effect of inhaled corticosteroids on the maximal degree of airway narrowing to methacholine in asthmatic subjects. Am Rev Respir Dis 1991;143:109-13.

59 Fuller RW, Choudry NB, Eriksson G. Action of budesonide on asthmatic bronchial hyperresponsiveness. Effects on directly and indirectly acting bronchoconstrictors. Chest 1991;100:670-4.

60 Laitinen LA, Laitinen A, Haahtela T. A comparative study of the effects of an inhaled corticosteroid, budesonide, and a beta 2-agonist, terbutaline, on airway inflammation in newly diagnosed asthma: a randomized, double-blind, parallel-group controlled trial. I Allergy Clin Immunol 1992;90:32-42.

61 Haahtela T, Jarvinen M, Kava T, et al. Comparison of a beta 2-agonist, terbutaline, with an inhaled corticosteroid, budesonide, in newly detected asthma. N Engl f Med 1991; 325:388-92.

62 O'Connor BJ, Ridge SM, Barnes PJ, et al. Greater effect of inhaled budesonide on adenosine 5'-monophosphateinduced than on sodium-metabisulfite-induced bronchoconstriction in asthma. Am Rev Respir Dis 1992;146:560-4.

63 Evans PM, O'Connor BJ, Fuller RW. Effect of inhaled corticosteroids on peripheral blood eosinophil counts and density pro

64 Vathenen AS, Knox AJ, Wisniewski A, et al. Time course of change in bronchial reactivity with an inhaled corticosteroid in asthma. Am Rev Respir Dis 1991;143:1317-21.

65 Wiebicke W, Jorres R, Magnussen H. Comparison of the effects of inhaled corticosteroids on the airway response to effects of inhaled corticosteroids on the airway response to
histamine, methacholine, hyperventilation, and sulfur dioxide in subjects with asthma. $f$ Allergy Clin Immunol 1990;86:915-23.

66 Verhagen AP, De Vet HCW, De Bie RA, et al. Delphi list: a criteria list for quality assessment of randomised clinical trials for conducting systematic reviews developed by Delphi consensus. F Clin Epidemiol 1998;51:1235-41

67 DerSimonian R, Laird N. Meta-analysis in clinical trials. Controlled Clin Trials 1986;7:177-88.

68 Selroos O, Pietinalho A, Lofroos AB, et al. Effect of early vs late intervention with inhaled corticosteroids in asthma. Chest 1995;108:1228-34.

69 Toogood JH. Complications of topical steroid therapy for asthma. Am Rev Respir Dis 1990;141:S89-96.

70 Guidelines for standardization of bronchial challenges with (nonspecific) bronchoconstricting agents. Bull Eur Physiopathol Respir 1983;19:495-514.

71 Hargreave FE, Ryan G, Thomson NC, et al. Bronchial responsiveness to histamine or methacholine in asthma: measurement and clinical significance. F Allergy Clin Immunol 1981;68:347-55.

72 van Schayck CP, Dompeling E, Molema J, et al. Does bronchial hyperresponsiveness precede or follow airway obstruction in asthma or COPD? Neth f Med 1994;45:14553.

73 Dompeling E, van Schayck CP, van Grunsven PM, et al. Slowing the deterioration of asthma and chronic obstructive pulmonary disease observed during bronchodilator therapy by adding inhaled corticosteroids. A 4-year prospective study. Ann Intern Med 1993;118:770-8.

74 Kerstjens HA, Brand PL, Hughes MD, et al. A comparison of bronchodilator therapy with or without inhaled corticosteroid therapy for obstructive airways disease. $N$ Engl f Med 1992;327:1413-9. 